\title{
From exclusion and segregation to inclusion? Dis/ability-based inequalities in the education systems of Germany and Nigeria
}

\author{
Julia Biermann and Justin J.W. Powell ${ }^{1}$
}

\section{Global context: from exclusion and segregation to inclusion in education systems}

While many groups have historically been marginalised in education systems, few groups have faced the same extent of exclusion and discrimination within formal education systems as the diverse group of pupils with disabilities, learning difficulties or disadvantages. These children and youth have been largely excluded from, segregated or separated within formal education systems, resulting in persistent inequalities in learning opportunities and in (lifelong) disablement and reduced life chances (Powell, 2011). A range of special education settings has been institutionalised, providing additional or specialised support to help these groups of learners to address their 'special needs'. Most often, such support and services were and continue to be provided in segregated or separated formal settings, such as special schools or classrooms. Special education has provided learning opportunities to groups of children and youth previously excluded outright from schooling, but globally the goal has shifted from special to inclusive education, due to the benefits it brings in fostering individual learning and democracy (for example, Allan, 2008). For all countries, whether in Africa, the Americas, Asia, Australia or Europe, this remains a challenge. Even the most egalitarian education systems, which have done the most to overcome outright exclusion from schooling have yet to succeed fully in schooling all children in diverse classrooms (see Richardson and Powell, 2011 for a global analysis; see also Biermann and Powell, 2014, comparing Germany, Iceland and Norway).

Definitions of inclusive education vary, and the necessary conditions and benefits of such programmes remain contested, as educators, 
researchers and policy makers struggle to apply and adapt pedagogical concepts and legal principles that insist on transformative change (for example, D'Alessio and Watkins, 2009). We thus examine here two contrasting cases: very different countries that strive to become more 'inclusive' but exhibit considerable barriers to inclusion. Nigeria, with a huge out-of-school population, endeavours to reduce prevalent exclusion from schooling, while Germany attempts to reduce persistent segregation in its special school system. As different as these countries are, policy makers and educators in both countries increasingly acknowledge that their systems require transformative reform to better meet the needs of all children and youth, whether through the United Nations (UN) Education for All framework or inclusive education. Indeed, both countries must do so to realise the legal and moral commitments that they made when they ratified the United Nations Convention on the Rights of Persons with Disabilities (UN-CRPD).

The global agenda for more inclusive schooling has gained momentum since adoption of the UN-CRPD in 2006 (UN, 2006), which emphasises inclusive education as a human right. ${ }^{2}$ A UN study of the rights of people with disabilities to education specifies that realising this requires education systems to: (1) achieve education for all (and thus reduce remaining outright exclusion) and (2) to combat discriminatory practices while providing needed supports and services to help individual learners to reach their potential (UN, 2013). The scope of inclusive education systems has been increasingly discussed, both during the convention's drafting process as well as during its truly globe-spanning ratification (in 159 countries thus far; UN, 2015), with the UN-CRPD aiming to reduce exclusion and segregation and ensure that inclusive classrooms are available for all pupils (Degener, 2009). The adaptation of the principles, standards and regulations required at different levels of education systems to implement such reforms requires significant effort, especially because education systems vary considerably in their institutionalisation, with considerable inertia and, when institutional change occurs, path dependence in school structures and cultures (see, for example, Powell, 2011; Blanck et al, 2013). Nevertheless, this international legal obligation demands that ratifying states guarantee non-discriminatory access to the general education system for people with disabilities, although the group of those considered to have special educational needs is both large and diverse.

The systematic exclusion or segregation of students on the basis of disability from, or within, the public formal school system is a violation of the principles and guidelines embedded, but underspecified, in the 
UN-CRPD (DIM, 2011; UN, 2013; UNICEF, 2013). Most countries have only begun to take the first steps to meet the obligations deriving from Article 24 of the UN-CRPD, which demand changes in terms of regulations, organisational structures and educational paradigms of almost all school systems worldwide. If the ideal of inclusive education remains elusive, there are countries, such as the Nordic countries, that not only guarantee access to the education system but also provide the necessary support for the majority of pupils with additional learning needs in inclusive classrooms (see Biermann and Powell, 2014). While global social movements and international organisations alter concepts, expectations and debates for national reforms (Dierkes and Zorn, 2005: 318), the achievement of the global disabled people's movement and organisations in developing the UN-CRPD must now be followed up by research into processes of institutional change after ratification (Blanck et al, 2013; Powell et al, 2015). From this perspective, we analyse and evaluate educational inequalities along the axis of dis/ ability in a major African country and a core European country, both of which are gradually committing to reform their education systems so as to foster more equality in learning opportunities for student groups often excluded or segregated on the basis of disability or disadvantage.

This contribution examines the (re)production of educational inequality and dis/ability in the process of appropriating the right to inclusive education in diverse contexts. Utilising a comparative approach, we examine the challenges of institutionalising inclusive education that requires, to some extent, a de-institutionalisation of established organisational forms that exclude, segregate or separate, and thus determine the educational opportunities of students with disabilities and the inequalities they face. Inclusive education policies aim to guarantee equal opportunity, equity and equal access to education for all, and thus confront prevalent exclusion and segregation (Agunloye, 2012). There are thus two overarching questions. What is currently understood as inclusive education at the policy level? In what ways do inclusive education reforms affect the historically evolved formal (special) school systems, changing educational opportunities for this group of students? We trace and compare the way educational disability has been institutionalised in two very different systems of schooling and how this determines contemporary efforts to implement obligations deriving from the ratification of the UN-CRPD.

We will introduce the study's scope, theoretical framework, case selection and methods applied, which partly derive from the first author's dissertation project. We then present two concise case studies that describe current school structures, categories of special educational 
needs, and attendance rates, as well as UN-CRPD-related policy reforms. We compare cases by briefly summarising the historical development of (special) school systems that determine the pathway(s) to inclusive education and thus influence the learning opportunities provided to students with disabilities, learning difficulties or disadvantages. In conclusion, we emphasise similarities and differences in terms of inequalities of learning opportunities for those perceived as having as special (educational) needs.

\section{Analysing educational inequalities and student dis/ability}

The analytical framework of this comparative case study comprises educational inequalities faced by children and youth with disabilities, learning difficulties or disadvantages, in two contrasting education systems. In the fields of special and inclusive education, a range of studies - from descriptive country studies to more ambitious historical and geographical comparisons - has examined the effects of internationalisation, delineated the rise of special and inclusive education worldwide and compared developments in different countries (for example, Peters, 1993; Mazurek and Winzer, 1994; Booth and Ainscow, 1998; Barton and Armstrong, 2001; Powell, 2011; Richardson and Powell, 2011; Tomlinson, 2013). We discuss educational inequalities in terms of institutionalised learning opportunity structures (Powell, 2011). With the focus on the availability of and access to formal schooling, we refer to the first two of four dimensions of the right to (inclusive) education, ${ }^{3}$ which also encompass acceptability and adaptability and that focus on the form and content of learning (UN CESCR 1999; see also Poscher et al, 2009; Platte, 2015). This operationalisation derives from the macro-sociological comparison focusing on special and inclusive education as institutionalised organisational forms, less as pedagogical approaches and teaching or learning practices. Children and youth excluded or in segregated special education face constraints on learning opportunities because exclusion from schooling or segregated learning environments emphasise particular differences between children as they classify, sort and often limit educational attainment. These differences often produce prejudice, negative stereotypes and discrimination against children and student groups, and determine life chances; however, these processes are characterised by a paradox: while the expansion of education counters outright exclusion, it simultaneously increases the stigmatisation of less educated youth (Solga, 2002) and the contemporary global growth of special education belies the increased emphasis on the global norm of inclusive education 
(Richardson and Powell, 2011). While teachers in special education often provide needed support, as a low-status educational track special education routinely increases stigmatisation and discrimination, even beyond schooling, as youth transition to labour markets (Pfahl, 2011; Tomlinson, 2013). For decades, special education classification and tracking systems have systematically excluded many children and youth from the learning opportunities, high expectations and rich curricula that would do most to prepare them for their futures (Powell, 2011).

We apply a broad conceptualisation of the group of children with disabilities, learning difficulties or disadvantages (OECD, 2007) to analytically grasp the diverse categories of special needs that not only refer to physical impairments but also include socioeconomic status and ethnicity. In many countries, we find persistent educational and social disadvantages suffered by children and youth with disabilities and learning difficulties, and the increased probability of socially and economically disadvantaged individuals becoming 'disabled' in school and later life. We therefore apply the term student disability to encompass the scope of special needs classifications and categories at the intersection of impairment, disadvantage, and social inequality in the field of education. Which students 'become disabled' in schooling depends significantly on special needs categories and the institutionalisation of the education system and its organisational forms.

\section{Case selection}

In this study, we discuss and compare educational provisions for children perceived as having special needs resulting from disabilities, disadvantages or difficulties in Nigeria and Germany. This raises the question of whether Nigeria, in directly implementing inclusive education reforms, could bypass the institutionalisation of segregated special schools as developed in Germany over the 20th century. We emphasise the complex relationship and complementarities between special and inclusive education in the respective school systems as these alter availability and access to formal education for this group of students. Both nation states have ratified the UN-CRPD and are legally committed to granting the right to education and implementing inclusive education systems, despite the inevitable loose coupling between national and local contexts and school levels. The countryspecific contexts are integral parts of the process in which inclusive education is negotiated and appropriated (Mitchell, 2005).

By selecting Germany and Nigeria, we apply a 'most different' case design in relation to the historical development of formalised 
schooling, the establishment of special schools as an independent school form, enrolment rates, and socioeconomic and demographic characteristics. Historically, Germany was a pioneer in institutionalising formal (special) education and schooling, yet today Germany lags behind many of its neighbours, with the vast majority of children with special needs and disabilities still educated in special schools, despite ratification of the UN-CRPD in 2009 (Powell, 2011). In Nigeria, the rise of a special education system is tied to the institutionalisation of formal education and schools, yet what began as a missionary and colonial project has morphed into a development project in the context of the UN framework of 'Education for All' (Biermann, 2015). The countries and their education systems differ widely in scope and space, as do poverty and income levels. Nigeria's population of roughly 174 million people is double Germany's 80 million (World Bank, 2014). Whereas Germany counts as a high-income country, almost $85 \%$ of the Nigerian population live on less than $\$ 2$ per day. Nevertheless, in relative terms, poverty in Germany affects almost one-fifth of children under 18 years (19.4\%) (Statistisches Bundesamt, 2014). In Germany, only $5 \%$ of children under 15 years of age did not attend school in 2010/11 (Statistisches Bundesamt, 2012), while Nigeria recorded 10.5 million out-of-school children - the highest number worldwide (UNICEF West and Central Africa Regional Office, 2014). Children and youth with disadvantages and disabilities thus face high probabilities of exclusion from schooling in Nigeria and segregation in Germany.

\section{Theoretical framework}

Explicit theorising is crucial for comparative case study research; when analysed in the light of specific theoretical concepts, the cases gain 'comparative merit' (Muno, 2009: 117). To analyse educational inequalities in relation to disability, we focus on the availability of and access to learning opportunities for children with disadvantages and disabilities in formal school systems. Sociological institutionalism offers a theoretical framework and analytical perspective that facilitates differentiation between three pillars of institutions: cultural-cognitive (beliefs and ideas), normative (standards, organisational forms, professions) and regulative (rules, regulations) (Scott, 2008; Powell, 2011). This facilitates an analysis of the principles of schooling, how school systems provide different settings and services to children with special needs (based on concepts of special or inclusive education and student dis/ability), and the respective education policies and legislation. 
As discussed above, the rise of international discourse and supranational policy making has led to isomorphic pressures. These become evident at many levels of education, from early childhood to higher education and lifelong learning, with educational reforms an expression of global movements and trends (Meyer and Ramirez, 2005). Developments in the countries studied emphasise the interplay of these international pressures and the institutionalisation pathways of formal school systems in countries that have accepted the UN-CRPD's obligation to become (more) inclusive. Despite such international pressures to reform structures and reach specific standards, national and local models and institutional arrangements in (special) education persist as incremental change occurs path dependently (Powell et al, 2015).

If the diffusion of international models is crucial in explaining institutional change across time and space, the concept of path dependence - increasing returns to existing institutional settings - helps to explain why, once established, institutions and organisational forms persist despite international isomorphic pressures. Once a path has been chosen, shifts or even departures from the established to an alternative institutional arrangement are difficult, because positive feedback processes consolidate the once chosen path. The range of options for subsequent policy making or institutional redesign are limited as formerly available institutional alternatives become increasingly inaccessible because of cumulative commitments and investments (see Ebbinghaus, 2009; Blanck et al, 2013 for application to special and inclusive education in Germany). We thus compare the institutional dimensions of the two formal school systems in relation to special and inclusive education, and then analyse processes of institutional persistence and change (in the penultimate section).

\section{Methods}

The methods used include content analysis of documents and official statistics paired with extensive fieldwork in both countries - interviews and participant observation in schools - by the authors. We analyse arguments, normative guidelines and organisational structures enshrined in policy documents, which alter the implementation of the UN-CRPD's tenets. The text corpus comprises official documents, policies and laws issued by the federal governments and education ministries with reference to special and inclusive education in schools. Accordingly, we focus mainly on content (not on the processes and circumstances in which these documents were produced, are consumed or exchanged; see Prior, 2003). These sources show 
how special and inclusive education have been conceptualised and distinguished (cultural-cognitive pillar), how standards have been defined, professional responsibilities delineated and organisational forms developed (normative pillar), and the policies and regulations enacted (regulative pillar).

\section{Case studies: from exclusion to segregation to inclusion?}

This section establishes the basis for the following macro-level comparison, outlining overarching trends in policies and delineating contemporary organisational forms. In particular, we focus on categories of special needs, related participation rates and contemporary education reforms, especially the impact of the UN-CRPD. We cannot here examine differences in education system institutionalisation across all states of both federal countries; however, large disparities by region, often along a north/south divide, do exist.

\section{Germany: a segregated special education system (with regional disparities)}

The German school system is highly stratified in organisational structure: four- or six-year common primary schooling is followed by vertically differentiated secondary schooling (Gymnasium, Realschule, Hauptschule, comprehensive schools, special schools). The most important distinction is that between general and special schools, which establishes a binary structure concentrating support services in special schools, although increasingly ambulatory services exist in some Bundesländer (see Blanck, 2014).

In such a stratified school system, pupils are sorted early according to biological, cognitive and social standards, with teacher evaluations and tests determining whether they deviate from average expected abilities. This is based on the Leitidee of 'homogenous learning groups' as the preferred type of instruction (see Preuss-Lausitz, 2014). Since 1994, the classification of 'special educational needs' (SEN; sonderpädagogischer Förderbedarf) includes several areas of support (and the respective categories or Förderschwerpunkte: learning, language, emotional-social development, mental disabilities, physical impairment, hearing, seeing, disease) (KMK, 1994). These areas of support define student disabilities and correspond to the differentiated school types in the special school system.

Since ratification of the UN-CRPD in 2009, the proportion of children with SEN attending regular schools has risen from $18.4 \%$ to 
$25 \%$ nationwide, but there is divergence among western German states, with Schleswig-Holstein an inclusion pioneer (less than 1\% special schooling at primary level) and Bavaria at up to $5 \%$ since ratification of the UN-CRPD (Blanck et al, 2013). The proportion of pupils in special schools has remained stable (4.6\% to $4.8 \%$ ), however, because ever more pupils are classified as having SEN (an increase from 6.0\% to $6.4 \%$; see Autorengruppe, 2014). The learning disability category accounts for the highest share among categories, at 40\%, although the dominance of this category has recently declined (Autorengruppe, 2014: 163). For decades, special school-leavers have constituted a large proportion of those with the lowest educational attainment, as three-quarters leave school without any qualification, with negative consequences for their future vocational careers and society (Pfahl, 2011).

In response, 12 of the 16 Bundesländer (and the federal government, Bundesregierung) have released action plans and debated far-reaching legal changes in education systems (DIM, 2015); recent research reveals, however, that while some state education laws have been adapted to the provisions enshrined in the UN-CRPD, none of the Länder meet all legal criteria constituting the right to inclusive education (Blanck, 2014). Germany as a whole has thus only partially developed school integration or educational inclusion, despite many local and regional successes (for example, Dorrance and Dannenbeck, 2013; Powell et al, 2015). The German parliament is preparing a Federal Participation Law (Bundesteilhabegesetz) to foster a more inclusive society.

In the context of inclusive education, the focus is on children with disabilities. Germany's core policy document 'Inclusive Education of Children and Youth with Disabilities in Schools', released by the Standing Conference of Education Ministers (KMK 2011), defines the expansion of inclusive education as a focus for special educators and refers broadly to the right to access the school system and the different types of schools, however:

Inclusive educational opportunities enable children and youth with disabilities or with a special educational need to have equal access to all opportunities for instruction, to the offerings of various educational programmes and to school life. [...] The need for education, counselling and the support of children and youth with disabilities differs individually. This also applies to the expectations and demands of parents with regard to the joint education of children and youth with and without disabilities or for 
specific educational programmes in special educational facilities. (KMK, 2011: 8, 13; authors' translation)

The National Action Plan, issued by the federal government in 2011 (BMAS, 2011), envisages continuous increases in inclusive schooling as the preferred option in many states; an explicit commitment to reduce school segregation is lacking in both documents, however. These efforts have been debated since 2011 in the Committee on the Rights of Persons with Disabilities, which officially examined the first state and shadow reports in March 2015. The segregated school system in particular evoked critical questions from committee experts before and during the meeting. In her concluding remarks, Diane Kingston, the committee expert acting as Country Rapporteur, urged Germany 'to do more to ensure that education was truly inclusive for all children with disabilities' (CRPD Committee, 2015).

Overall, the UN-CRPD and Article 24 have become a priority on the political agenda and in public debate, with considerable implications for the core conflict of education policy making - the stratified secondary school structures; however, path-dependent institutionalisation processes reflect both more inclusion and more segregation, with considerable divergence between the Länder (Blanck et al, 2013; Powell et al, 2015). We now turn from one of the largest countries in Europe to the most populous African country - similarly challenged by the global norm of inclusive education.

\section{Nigeria: special education as a response to exclusion and inclusion in the context of Education for All}

The Nigerian school system is divided into two broad sectors: basic education, which covers the first nine years of schooling (six years primary and three years junior secondary education), and three years of senior secondary. We refer here mainly to basic education and the distinction between children in school and not in school, and less to socioeconomic segregation in the context of access to public or private schools, which is also considerable, but for which limited data exists.

Today, the education system faces serious challenges in terms of providing and maintaining meaningful access to any formal education (see Obanya, 2011). In total, 10.5 million children do not attend school at all (UNESCO, 2012), the highest number worldwide for any single country; however, enormous disparities exist within this group in relation to gender, residence, region, economic status and dis/ ability. The highest rate of attendance is recorded for urban males with 
a high socioeconomic status, and children doing Qu'ranic schooling ('almajiris') count as one of the largest groups among out-of-school children (Hoechner, 2013; Taiwo, 2013). More than 70\% of women in the north have never attended school compared to less than $20 \%$ in the south (NPC/RTI International, 2011). The rural-urban inequality in terms of access to schooling worsened between 2003 and 2013, as the primary attainment rate among the poorest households fell from $35 \%$ in 2003 to 22\% in 2013 (UNESCO, 2015: 81, 83). Half of those with disabilities do not benefit from any form of formal education (Federal Republic of Nigeria, 2011: 99); a few public and some private schools, founded and maintained by churches, philanthropic organisations or parents, cater to students with disabilities, mainly with sensory impairments (Agunloye, 2012: 18). ${ }^{4}$

The National Policy on Education refers to three groups targeted by special education: the disabled, the disadvantaged, and the gifted and talented (Federal Republic of Nigeria 2004, 47). ${ }^{5}$ The category of 'the disabled' includes people who have an impairment of their vision, hearing, speech, or have a physical or health impairment, who are 'learning disabled', multiply handicapped - or those who face mental or emotional challenges. While these categories are enshrined at the policy level, there are no officially regulated diagnostic procedures that lead to an official statement of a special (educational) need, which could generate additional or specialised resources or have an impact on school placements. The compulsory school law, the Universal Basic Education (UBE) Act from 2004, lists nomads and migrants, 'girlchildren' and women, almajiri, street children and 'disabled groups' as 'special groups'. These groups are vulnerable to exclusion from, and marginalisation within, formal school systems.

This broad approach to special groups and special needs is reflected in Nigerian conceptualisations of 'inclusive education'. The federal government and some states have started to develop inclusive education policies; however, it is the Disability Bill that overshadows the UNCRPD as a key reference and is a call to action (Biermann, 2015). The Disability Bill, not yet passed, ${ }^{6}$ mandates: 'All (public) schools [...] shall be run to be inclusive of and accessible to persons with disabilities, accordingly every school shall have [...] (b) special facilities for the effective education of persons with disabilities' (The Senate, Federal Republic of Nigeria, 2013: 23). In the same vein, the National Policy on Education mandates that: 'All necessary facilities that would ensure easy access to education shall be provided, e.g. inclusive education or integration of special classes and units into ordinary/public schools under UBE scheme' (Federal Republic of Nigeria, 2004:

[[Note said "brackets for information not added". Please confirm whether there were in the original quote? If added by you they should be square brackets.]] 
49). Inclusive education is thus viewed as encompassing the growth of special education and complementing the path to universal basic education (nine years of schooling), thus serving as an instrument to institutionalise Education for All (EFA) (see also Anaduaka and Okafor, 2013), but Nigeria received a dismal assessment in the final report evaluating global EFA achievements since 2000, because 'Nigeria has lacked progress in nearly all education indicators' (UNESCO, 2015: $81)^{7}$

In summary, categories of special needs in both countries relate to socioeconomic disadvantage and disability as perceived bodily impairments or cognitive challenges. In Germany, the vast majority of children identified as having SEN are segregated in special schools within highly stratified state education systems. Nigeria's education system, by contrast, is characterised by the exclusion of a vast of number of children, whatever their dis/ability status. The global norm of inclusive education is a major challenge for both countries, regardless of their economic, social and political development. In confronting this problem, understanding the institutional dimensions of schooling is crucial in gauging change.

\section{Comparing countries: pathways away from or towards inclusive education?}

Here we explicitly compare the two countries and, in particular, their school systems in relation to special and inclusive education, as this reveals the principles and policies that structure educational opportunities in terms of their availability, and access to them for children with SEN. We summarise the institutional dimensions, highlighting the sometimes contradictory and sometimes complementary relationship between special and inclusive education. Reform processes to implement the right to inclusive education are embedded in these contexts, which exhibit both institutional persistence and change as Germany and Nigeria react to the commitments UN-CRPD ratification brought.

\section{Institutional dimensions of school systems in relation to special and inclusive education}

The cases demonstrate considerable variation in the three institutional dimensions: the ideas and concepts embedded in special and inclusive education, organisational forms and classification systems relating to (student) disability, and special and inclusive education policy making. Here, we briefly discuss each institutional dimension based on our 
analysis of official documents and scientific literature (see Table 10.1). This compilation is non-exhaustive; statements should thus be considered as ideal-types that help to emphasise certain commonalities and differences but that vary within these culturally and politically decentralised countries.

Germany maintains one of Europe's highest levels of school segregation, where children with student disabilities are mostly educated in special schools (Blanck et al, 2013). Inclusive education policy making, thus, basically involves school reforms targeting structures, and a shift in special education expertise to regular schools, which further maintains 'student disability', since some pupils are still considered in need of specialised teachers, materials and programmes based on their classification in relation to expectations of 'normal' abilities, even as these expectations differ considerably across schools. The Nigerian system, in contrast, can be described as exclusionary. Especially for children with disabilities, schools remain largely unavailable or inaccessible. Calls for inclusive education paradoxically imply the institutionalisation of special education services, since these are, if at all, available in (segregated) special education settings. This response to international pressure to become more inclusive results in a perverse expansion of organisational forms that are not compatible with - and in fact, contradict - the spirit of the UN-CRPD.

Institutionalised school systems in both countries (re)produce and maintain inequalities in learning opportunities, especially of those with student disabilities. The groups targeted, however, are not identical. In Germany, inclusive education is discussed in relation to the eight types of student disability analogous to special education's support areas. By contrast, the focus in Nigeria is on children with disabilities when it comes to special education, and on socially disadvantaged and marginalised groups when it comes to the general failings of the public school system (and regular schools). The concept of inclusion is far broader in Nigeria than in Germany, as a result of the widespread poverty and disadvantage faced by so much of the school-aged population, with emphasis on reducing widespread exclusion (inclusion in the education system). In Germany, the challenge is to reduce school segregation in favour of inclusive classrooms serving all children and youth, whatever their dis/ability.

The comparison of these contrasting cases emphasises the interdependence of special and inclusive education, but from different angles. In Germany, the debate mainly focuses on school structures and settles on a (gradual) shift of special education expertise from special to regular schools. In Nigeria, by contrast, inclusive education is a 
Table 10.1: Institutional dimensions of special and inclusive education in Germany and Nigeria

\begin{tabular}{|c|c|c|}
\hline & Germany & Nigeria \\
\hline Formal public schooling is & stratified, segregated & exclusionary \\
\hline \multicolumn{3}{|c|}{ Beliefs and ideas (concepts of special and inclusive education) } \\
\hline Inclusion & \multicolumn{2}{|c|}{$\begin{array}{l}\text { 'contemporary' concept requiring debate in } \\
\text { social, political and scientific arenas }\end{array}$} \\
\hline Inclusive education & $\begin{array}{l}\text { a challenging school } \\
\text { reform (widespread } \\
\text { maintenance of } \\
\text { special schools) }\end{array}$ & $\begin{array}{l}\text { an instrument to } \\
\text { institutionalise 'Education } \\
\text { for All' through expanding } \\
\text { special education }\end{array}$ \\
\hline Special education & $\begin{array}{l}\text { serves those pupils } \\
\text { with recognised special } \\
\text { educational needs (KMK, } \\
\text { 2013) }\end{array}$ & $\begin{array}{l}\text { formal education provided } \\
\text { to those children and } \\
\text { adults with recognised } \\
\text { special needs (Federal } \\
\text { Republic of Nigeria, 2004) }\end{array}$ \\
\hline \multicolumn{3}{|c|}{ Norms (organisational forms and classification systems) } \\
\hline $\begin{array}{l}\text { Key barrier to equal learning } \\
\text { opportunities for all students }\end{array}$ & $\begin{array}{l}\text { large, differentiated } \\
\text { system of special schools }\end{array}$ & $\begin{array}{l}\text { deficient public school } \\
\text { system }\end{array}$ \\
\hline Historically, special schools & $\begin{array}{l}\text { grew into a distinct type } \\
\text { of school in most cities } \\
\text { from } 1900\end{array}$ & $\begin{array}{l}\text { were single schools } \\
\text { first introduced by } \\
\text { missionaries in the } 1850 \text { s }\end{array}$ \\
\hline Recently, special schools & $\begin{array}{l}\text { host the majority of } \\
\text { students with SEN }\end{array}$ & $\begin{array}{l}\text { only available for a very } \\
\text { few students }\end{array}$ \\
\hline $\begin{array}{l}\text { Classification of special } \\
\text { (educational) needs }\end{array}$ & $\begin{array}{l}\text { eight official support } \\
\text { categories, including } \\
\text { 'learning disability' }\end{array}$ & $\begin{array}{l}\text { three groups: disabled, } \\
\text { disadvantaged, highly } \\
\text { gifted }\end{array}$ \\
\hline \multicolumn{3}{|c|}{ Regulations (policies and legislation) } \\
\hline Relevant international policies & UN-CPRD & $\begin{array}{l}\text { EFA, Millennium } \\
\text { Development Goals }\end{array}$ \\
\hline Legislation & $\begin{array}{l}\text { state school laws and } \\
\text { action plans, 'participation } \\
\text { law' Bundesteilhabegesetz } \\
\text { (not yet passed) }\end{array}$ & $\begin{array}{l}\text { Universal Basic Education } \\
\text { Act, Disability Bill (not yet } \\
\text { passed) }\end{array}$ \\
\hline
\end{tabular}

Sources: Powell (2011), Biermann and Powell (2014), Biermann (2015).

development project in the context of EFA in Nigeria, whose overall target is to institutionalise a functioning, formalised 'Western-model' education system (see also Kendall, 2009; Harber, 2014). In both countries, becoming more 'inclusive' paradoxically results in attempts to maintain, or even expand, special education expertise and settings, which ultimately leads to inclusive education being subverted and a renewal of special education ('Sonderpädagogisierung der Inklusion'). 
To summarise, special education and special schools retain legitimacy in both cases, even though this contradicts the principles of the human right to inclusive education codified in international charters, from Salamanca (1994) to the UN-CRPD (2006); however, whether special schools are barriers to inclusive education or, alternatively, necessary for the development of inclusive education, remains a contentious matter (see Degener, 2009; Powell, 2011; Richardson and Powell 2011), and affects implementation of the right to inclusive schooling as anchored in the UN-CRPD's Article 24. Although the hope of decreasing educational inequality by developing inclusive school systems is openly debated in terms of organisational forms and professional standards (norms), as well as in terms of policy making (regulations), the reforms disregard beliefs, underlying cultural meanings ascribed to schooling and dis/ability paradigms in general (ideas).

\section{Institutional persistence and change}

To analyse these current trends, debates and reform initiatives, we chart their shifting historical contexts, showing institutional persistence and change in relation to the commitments made upon ratifying the UNCRPD. This requires an understanding of the different developmental paths upon which school systems have evolved. Such an analysis must embrace discussion of the complex relationship - contradictions and complementarities - between special and inclusive education.

The concept of path dependence facilitates investigation of gradual educational change in Germany's 16 states (Länder), while at the same time elucidating why segregated structures may persist despite ratification of the UN-CRPD. Special schooling, in particular, has shown considerable inertia due to ideational, normative and regulative barriers to inclusive education. From around 1900, special schools were developed as a separate school form as part of highly stratified education systems that emphasised 'homogenous learning groups' (Powell, 2011). With the universalisation of compulsory schooling and special education's expansion during the post-Second World War period, the German system was organisationally differentiated, including a wide array of special school types. Despite successful pilot projects in inclusion since the 1970s (Schnell, 2003; Preuss-Lausitz, 2014), professional, parental and political interests continue to conform to the institutional logic of special schooling. Conflicts between the persistence of legitimated selection for special schools (with many resources, but low status) and change towards inclusion continue. Here, the steady and continuing expansion of special education in West 
Germany since the 1960s confronts the transformation of education in the new Länder, paradoxically leading to dramatic increases in special schooling rates after reunification (Autorengruppe, 2014). The influence of the special education profession, oriented towards differentiated, segregated special school types, remains a key factor in the thwarted development of inclusive education (Pfahl and Powell, 2011). Schooling in Germany can therefore be characterised by the paradox of gradually increasing inclusive education, simultaneously with maintained school segregation for three-quarters of all pupils with SEN, accompanied by increased rates of classification and provision of special education services.

By contrast, analysing institutional persistence and change towards inclusive education in Nigeria is not about overcoming a far-reaching special school system. What could be seen as a 'late-adopter' advantage, however, is limited by the international model of schooling itself. For that reason, we can find an over-representation of children from ethnic minorities and low-income households in Germany's special schools, which parallels their over-representation in Nigeria's public schools and especially within the out-of-school population. The overwhelming majority of children in public schools are (extremely) poor - and not officially considered 'disabled', but are in multiple senses disadvantaged. The attempt to institutionalise formal public schooling was and still is a process that has contributed neither to individual aspirations nor societal welfare. In the 1840 s, missionaries founded formal and (later) special schools; from the 1880s, the colonial administration introduced the first educational policies in the territory that became Nigeria in 1912. Following independence from colonial rule (1960), attempts were directed to unifying the public school system through nationwide legislation and universal primary education programmes. An economic downturn coupled with an oil crisis in the late 1980s rendered the school system close to collapse. A revitalisation of basic education under the umbrella of international development frameworks started in the 1990s, with diverse education sector support programmes and a host of international organisations (see Federal Ministry of Education, 2005; Ayeni and Dada, 2011).

Today, the public school system is under the 'guidance' of diverse international organisations and development frameworks (Agunloye, 2012, 19); a similar influence can be seen within the disability rights regime (Biegon, 2011). Schooling, once used as a 'civilising' force in colonial times that meant 'literacy for a few', has become 'schooling for some' and does not provide meaningful (inclusive) education for all. This is especially the case because a narrow approach to education 
prevails that equates EFA with formal schooling and thus ignores informal or indigenous forms of learning (see Brock-Utne, 2000). Accordingly, the influence of Western and then global concepts, models and pressures in the process of institutionalising a formal school system, has been present since inception, and thus incorporates (the rhetoric of) inclusive education in the processes of providing EFA to meet the goals of universal basic education.

The comparison of Germany and Nigeria highlights the importance of legacies as education and school systems gradually expand: in the former, as a pioneer in special education, the continued reliance on special schools as an early innovation to counter exclusion; and in the latter the establishment of special and regular schools during colonial times as a limited solution for a selected few. The general phases of development seen around the world, from exclusion to inclusion, have not been compressed in these two countries. In fact, the relationship between special and inclusive education in both cases is complex, because inclusion is viewed by many as requiring the interventions of special education as a profession, within established settings, so that special schools and classrooms become the 'solution' to not only counter exclusion from schooling, but also to accomplish what they cannot: to enable inclusion (see, for example, Tomlinson, 2013). We have argued that Germany subverts inclusion in favour of strengthening existing special schools. Vitriolic debate on school structures and the hollow pledge to increasingly open general schools for children with SEN reflect this pattern. Overall, conditions for inclusive education are not being met, and the shift in special education expertise into general schools has been limited. In Nigeria, the goal to achieve Education for All now encompasses the expansion of special education and the establishment of special schools, special classes or classes for all; however, the limited resources provided for schooling and widespread poverty result in a tremendous gap between national policy rhetoric and reality in communities, especially in the north.

\section{Conclusions}

We now return to our initial expectation that international pressure to promote inclusive education would alter established educational structures. Focusing on educational inequalities and (student) disability and disadvantage, we find that inclusive education is rising up the political agenda. It gives rise to controversy in the selected, contrasting, African and European cases. Rhetorically, inclusive education and the right to equal learning opportunities of children with student 
disabilities have become increasingly significant in contemporary education policy making and schooling. Path-dependent developments within each country also result in different principles and approaches to inclusive education. These are tied to the institutionalisation of general formal and special education, with the continued maintenance or indeed the paradoxical expansion of special schools and classrooms in both countries. While special education programmes that segregate or separate contradict the globally accepted principle of inclusion, these institutionalised organisational forms cannot be ignored when discussing the theory and practice of inclusive schooling in these currently exclusionary (Nigeria) and segregated (Germany) contexts.

The analysis of institutionalised inequalities in learning opportunities provided for students disabled in and by schooling offers broader insights into the dynamics of change in education systems. For that reason, the question of whether Nigeria could circumvent segregation in special schools that developed in Germany, demands an understanding that the outright exclusion and the provision of segregated special schooling reflect institutional discrimination embedded in the arrangements of formal schooling that follows powerful Western models of selective, stratified and stigmatising school forms. Nigeria's huge out-of-school population and Germany's stratified and segregated (special) school systems result in the inaccessibility of regular schools and classrooms for the majority of children with disabilities and thus reduce the learning opportunities provided.

These institutionalised exclusionary and segregating processes favour a norm-group deemed able to cope with regular provision and simultaneously (re)produce educational inequalities. Whereas the most disadvantaged in Germany are over-represented in stigmatising special schools, in Nigeria this group remains largely excluded from formal schooling altogether. The Nigerian context therefore exhibits institutionalised discrimination in one of its most extreme forms, where primarily one select group benefits from schooling and all others are accordingly distinguished as 'special' groups; they suffer various inequalities in accessing the curriculum. Even when the outright exclusion of pupils with disabilities has been overcome through the development of special education programmes, these frequently have an over-representation of boys, ethnic minorities (and children from migrant families), and children living in families with low socioeconomic status (a pattern found in many parts of the world; see Richardson and Powell, 2011).

Special education's segregated settings testify to the continuous construction of educational differences, disadvantages and disabilities. 
Educational stratification reproduces and exacerbates inequalities in education and society. In Germany, the impact of socioeconomic status in schooling is hard to overestimate as family background and education determine educational access, achievement and attainment, but inclusive schooling also depends to a large extent on the Bundesland in which one lives. In Nigeria, family income determines access to formal education and educational opportunities, as does region, with large north/south disparities.

Paradoxically, the context-specific construction of inclusive education programmes after ratification of the UN-CRPD has led to the expansion and further development of segregated special education forms instead of more inclusive arrangements. The stigmatisation of this group of students continues, even when the policy rhetoric emphasises the benefits of inclusion. Accordingly, there is a huge gap between inclusion principles in discourse and policy making internationally, and the further expansion and elaboration of special education found in Germany and Nigeria at national and local levels. These developments contradict the goal of making education systems more inclusive, and are thus barriers to attaining the global norm of inclusive education as a human right.

\section{Notes}

1. We thank Christian Brüggemann and Jennifer Dusdal and the reviewers for helpful comments on earlier drafts of this chapter. Julia Biermann's doctoral work was funded by the Friedrich Naumann Foundation.

2. At the international level, the Salamanca Statement of 1994 first stated that the 'fundamental principle of the inclusive school is that all children should learn together, wherever possible, regardless of any difficulties or differences they may have' (UNESCO, 1994 [[not in the refs, please add]]: 11).

3. The accuracy of this fit can be traced to the Global Survey on Government Action on Implementation of the UN Standard Rules on the Equalisation of Opportunities for Persons with Disabilities (2006), which found that the 'real gap in the area of education lies between availability and accessibility' (UN ECOSOC, 2007.

4. We lack data on the number of children with disabilities in (special) schools and different structures in Nigeria. Nevertheless it is noteworthy that half of all people with disabilities in schools reported awareness of discrimination against them (Federal Republic of Nigeria, 2011, 144). Of course, this is a highly selective group and furthermore their (tenuous) participation may hinder them from acknowledging active discrimination.

5. The first version of the National Policy on Education from 1977 mentioned integration as 'the most realistic form of special education' (Abang, 1992: 14f.; Garuba, 2003: 179). 
6. The new president-elect, General Muhammadu Buhari, has promised in an open letter to the Nigerian public ('My Covenant with Nigerians') to work with the National Assembly to finally pass the National Disability Act.

7. But, as Brock-Utne (2000) explains, the declining enrolment rates and increasing dropout rates may relate to the inappropriateness of education offered in schools.

\section{References}

Abang, T. (1992). Special education in Nigeria. International Journal of Disability, Development and Education, 29(1), 13-18.

Agunloye, O.O. (2012). Inclusive Education: Principles and Concepts. Jos: Saniez Books.

Allan, J. (2008). Rethinking Inclusion. Dordrecht: Springer.

Anaduaka, C. and Okafor, F. (2013). The Universal Basic Education (UBE) programme in Nigeria. Basic Research Journal of Education Research and Review, 2(3), 42-48.

Autorengruppe Bildungsberichterstattung (2014). Bildung in Deutschland 2014. Bielefeld: W. Bertelsmann.

Ayeni, M.A. and Dada, M.A. (2011). An exploration into the education innovations in Nigeria in the last two decades. Journal of Emerging Trends in Educational Research and Policy Studies, 2(4), 199-205.

Barton, L. and Armstrong, F. (2001). Disability, education, and inclusion: Cross-cultural issues and dilemmas. In G.L. Albrecht, K.D. Seelman and M. Bury (eds), Handbook of Disability Studies. Thousand Oaks, CA: Sage, 693-710.

Biegon, J. (2011). The promotion and protection of disability rights in the African human rights system. In: I. Grobbelaar-du Plessis and T. van Reenen (eds), Aspects of Disability Law in Africa. Pretoria: Pretoria University Law Press, 53-83.

Biermann, J. (2015). Der Einfluss der UN-Behindertenrechtskonvention auf die Entwicklung inklusiver Schulsysteme: Eine Fallstudie aus Nigeria. In A. Leonhardt, K. Müller and T. Tuckenbrodt (eds), Die UN-Behindertenrechtskonvention und ihre Umsetzung. Bad Heilbrunn: Klinkhardt, 297-305.

Biermann, J. and Powell, J.J.W. (2014). Institutionelle Dimensionen inklusiver Schulbildung: Herausforderungen der UNBehindertenrechtskonvention für Deutschland, Island und Schweden im Vergleich. Zeitschrift für Erziehungwissenschaften, 17(4), 679-700. Blanck, J.M. (2014). Organisationsformen schulischer Integration und Inklusion: Eine vergleichende Betrachtung der 16 Bundesländer. WZB Discussion Paper SP I 2014-501. Berlin: Wissenschaftszentrum Berlin für Sozialforschung. 
Blanck, J.M., Edelstein, B. and Powell, J.J.W. (2013). Persistente schulische Segregation oder Wandel zur inklusiven Bildung? Die UNBehindertenrechtskonvention und mechanismen in den deutschen Bundesländern. Schweizerische Zeitschrift für Soziologie, 39(2), 267-292.

BMAS (2011). Unser Weg in eine inklusive Gesellschaft: Der Nationale Aktionsplan der Bundesregierung zur Umsetzung der UNBehindertenrechtskonvention. Berlin: Bundesministerium für Arbeit und Soziales.

Booth, T. and Ainscow, M. (eds) (1998). From Them to Us: An International Study of Inclusion in Education. London: Routledge.

Brock-Utne, B. (2000). Whose Education for All? The Recolonization of the African Mind. New York: Falmer.

CRPD Committee (2015). Committee on the Rights of Persons with Disabilities considers initial report of Germany. http://www.ohchr.org/EN/ NewsEvents/Pages/DisplayNews.aspx?NewsID=15769\&LangID=E.

D'Alessio, S. and Watkins, A. (2009). International comparisons of inclusive policy and practice. Research in Comparative and International Education, 4(3), 233-249.

Degener, T. (2009). Die UN-Behindertenrechtskonvention als Inklusionsmotor. Recht der Jugend und des Bildungswesens, 57(2), 200-219.

DIM (Deutsches Institut für Menschenrechte) (2011). Eckpunkte zur Verwirklichung eines inklusiven Bildungssystems. www.institut-fuermenschenrechte.de/uploads/tx_commerce/stellungnahme_der_ monitoring_stelle_eckpunkte_z_verwirklichung_eines_inklusiven_ bildungssystems_31_03_2011.pdf.

DIM (2015). Stand der Aktions- und Maßnahmenpläne zur Umsetzung der UN-BRK in Bund und Ländern. www.institut-fuer-menschenrechte. de/monitoring-stelle/monitoring/aktions-und-massnahmenplaene/ uebersicht-zum-stand-der-aktionsplaenemassnahmenplaene-zurumsetzung-der-un-brk-in-bund-und-laendern/.

Dierkes, J. and Zorn, D. (2005). Soziologischer Neoinstitutionalismus. In: D. Kaesler (ed.), Aktuelle Theorien der Soziologie. Munich: Beck, 313-331.

Dorrance, C. and Dannenbeck, C. (eds) (2013). Doing Inclusion: Inklusion in einer nicht inklusiven Gesellschaft. Bad Heilbrunn: Klinkhardt.

Ebbinghaus, B. (2009). Can path dependence explain institutional change? In L. Magnusson and J. Ottosson (eds), The Evolution of Path Dependence. Cheltenham: Elgar, 191-212.

Federal Ministry of Education (2005). Nigeria Education Sector Diagnosis. Abuja: Federal Ministry of Education. 
Federal Republic of Nigeria (2004). National Policy on Education. Lagos: NERDC Press.

Garuba, A. (2003). Inclusive education in the 21st century: Challenges and opportunities for Nigeria. Asia Pacific Disability Rehabilitation Journal, 14(2), 191-200.

Harber, C. (2014). Education and International Development. Oxford: Symposium Books.

Hoechner, H. (2013). Searching for Knowledge and Recognition: Traditional Qur'anic Students in Kano, Nigeria. French Institute for Research in Africa (IFRA-Nigeria), University of Ibadan.

Kendall, N. (2009). International development education. In R. Cowen and M. Kazamias (eds), International Handbook of Comparative Education. London: Springer, 417-436.

KMK (Kultusministerkonferenz) (1994). Empfehlungen zur sonderpädagogischen Förderung in den Schulen in der Bundesrepublik Deutschland. Beschluss der Kultusministerkonferenz vom 6 May1994.

KMK (2011). Inklusive Bildung von Kindern und Jugendlichen mit Behinderungen in Schulen. Beschluss der Kultusministerkonferenz vom 20 October.

Mazurek, K. and Winzer, M. (eds) (1994). Comparative Studies in Special Education. Washington, DC: Gallaudet University Press.

Meyer, J.W. and Ramirez, F.O. (2005). Die globale Institutionalisierung der Bildung. In J.W. Meyer (ed.), Weltkultur. Frankfurt am Main: Suhrkamp, 212-234.

Mitchell, D. (2005). Introduction: Sixteen propositions on the context of inclusive education. In D. Mitchell (ed.), Contextualizing Inclusive Education. London: Routledge, 1-21.

Muno, W. (2009). Fallstudien und die vergleichende Methode. In S. Pickel (ed.), Methoden der vergleichenden Politik- und Sozialwissenschaft. Wiesbaden: VS Verlag, 113-131.

NPC and RTI International (2011). Nigeria Demographic and Health Survey (DHS) Data Profile: Education Data for Decision-Making 2011. Washington, DC: National Population Commission and RTI International.

Obanya, P. (2011). Politics and the Dilemma of Meaningful Access to Education: The Nigerian Story. CREATE Pathways to Access, Research Monograph 56. www.create-rpc.org/pdf_documents/PTA56.pdf.

OECD (2007). Students with Disabilities, Learning Difficulties and Disadvantages. Paris: Organisation for Economic Co-operation and Development.

Peters, S.J. (ed.) (1993). Education and Disability in Cross-cultural Perspective. New York: Garland. 
Pfahl, L. (2011). Techniken der Behinderung. Bielefeld: transcript.

Pfahl, L. and Powell, J.J.W. (2011). Legitimating school segregation. Disability E Society, 26(4), 449-462.

Platte, A. (2015). Inklusive Bildung: Leitidee von der Kindertageseinrichtung bis zur Hochschule. In T. Degener and E. Diehl (eds), Handbuch Behindertenrechtskonvention. Bonn: Bundeszentrale für politische Bildung, 130-146.

Poscher, R., Rux, J. and Langer, T. (2009). Das Recht auf Bildung. Baden-Baden: Nomos.

Powell, J.J.W. (2011). Barriers to Inclusion: Special Education in the United States and Germany. Boulder, CO: Paradigm Publishers.

Powell, J.J.W., Edelstein, B. and Blanck, J.M. (2015). Awarenessraising, legitimation or backlash? Effects of the UN Convention on the Rights of Persons with Disabilities on education systems in Germany. Globalisation, Societies and Education, online first: doi 10.1080/14767724.2014.982076.

Preuss-Lausitz, U. (2014). Wissenschaftliche Begleitungen der Wege zur inklusiven Schulentwicklung in den Bundesländern. Versuch einer Übersicht. Bonn: Deutsche UNESCO-Kommission e.V. www.unesco.de/fileadmin/medien/Dokumente/Bildung/Wiss Begleitung_Inklusion_end_2_.pdf.

Prior, L. (2003). Using Documents in Social Research. London: Sage.

Richardson, J.G. and Powell, J.W. (2011) Comparing Special Education: Origins to Contemporary Paradoxes. Stanford, CA: Stanford University Press.

Schnell, I. (2003). Geschichte schulischer Integration. Weinheim: Juventa. Scott, W.R. (2008). Institutions and Organizations. Thousand Oaks, CA: Sage.

Solga, H. (2002). 'Ausbildungslosigkeit' als soziales Stigma in Bildungsgesellschaften. Kölner Zeitschrift für Soziologie und Sozialpsychologie, 54(3), 476-505.

Statistisches Bundesamt (2012). Schulen auf einen Blick. Wiesbaden: Statistisches Bundesamt.

Statistisches Bundesamt (2014). 20.3\% der Bevölkerung Deutschlands von Armut oder sozialer Ausgrenzung betroffen. Pressemitteilung 454. www.destatis.de/DE/PresseService/ Presse/Pressemitteilungen/2014/12/PD14_454_634pdf.pdf? blob=publicationFile.

Taiwo, FJ. (2013). Transforming the Almajiri education for the benefit of the Nigerian society. Journal of Educational and Social Research, 3(9), $67-72$. 
The Senate, Federal Republic of Nigeria (2013). A Bill for an Act to Ensure Full Integration of Persons with Disabilities into the Society and to Establish a National Commission for Persons with Disabilities and Vest it with the Responsibilities for their Education, Health Care and the Protection of their Social, Economic, Civil Rights. Abuja: The Senate, Federal Republic of Nigeria.

Tomlinson, S. (2013). Ignorant Yobs: Low Attainers in a Global Knowledge Economy. London: Routledge.

UN (United Nations) (2006). Convention on the Rights of Persons with Disabilities. UN General Assembly: A/RES/61/106.

UN (2013). Thematic Study on the Right of Persons with Disabilities to Education. UN General Assembly, Human Rights Council: A/ $\mathrm{HRC} / 25 / 29$.

UN (2015). Conventions and Optional Protocol Signatures and Ratifications. www.un.org/disabilities/countries.asp?navid=12\&pid=166.

UN CESCR (United Nations Committee on Economic, Social and Cultural Rights) (1999). General Comment No. 13, The Right to Education. E/C.12/1999/10.

UN ECOSOC (United Nations Economic and Social Council) (2007). Report of the Special Rapporteur on Disability of the Commission for Social Development on monitoring of the implementation of the Standard Rules on the Equalization of Opportunities for Persons with Disabilities. E/CN.5/2007/4.

UNESCO (1994). The Salamanca Statement and Framework for Action on Special Needs Education. http://www.unesco.org/education/pdf/ SALAMA_E.PDF.

UNESCO (2012). Education for All Global Monitoring Report, Fact Sheet 12, Education in Nigeria. https://en.unesco.org/gem-report/sites/ gem-report/files/NIGERIA_FACT_SHEEET.pdf.

UNESCO (2015). Education for All 2000-2015: Achievements and Challenges. Paris: UNESCO.

UNICEF (2013). The State of the World's Children 2013. New York: UNICEF.

UNICEF West and Central Africa Regional Office (2014). All Children in School by 2015, Global Initiative on Out-of-School-Children: Regional Report West and Central Africa. www.unicef.org/education/files/ RR_OutOfSchoolVA_BAT.pdf.

World Bank (2014). World Development Indicators. data.worldbank.org. 


\section{EDUCATION SYSTEMS AND INEQUALITIES \\ International comparisons}

Edited by Andreas Hadjar and Christiane Gross 
First published in Great Britain in 2016 by

\author{
Policy Press \\ University of Bristol \\ 1-9 Old Park Hill \\ Bristol \\ BS2 8BB \\ UK \\ t: +44 (0)117954 5940 \\ pp-info@bristol.ac.uk \\ www.policypress.co.uk
}

North America office:

Policy Press

c/o The University of Chicago Press

1427 East 60th Street

Chicago, IL 60637, USA

t: +17737027700

f: +1 773-702-9756

sales@press.uchicago.edu

www.press.uchicago.edu

\section{(C) Policy Press 2016}

British Library Cataloguing in Publication Data

A catalogue record for this book is available from the British Library

Library of Congress Cataloging-in-Publication Data

A catalog record for this book has been requested

ISBN 978-1-4473-2610-6 hardcover

The right of Andreas Hadjar and Christiane Gross to be identified as editors of this work has been asserted by them in accordance with the Copyright, Designs and Patents Act 1988.

All rights reserved: no part of this publication may be reproduced, stored in a retrieval system, or transmitted in any form or by any means, electronic, mechanical, photocopying, recording, or otherwise without the prior permission of Policy Press.

The statements and opinions contained within this publication are solely those of the contributors and editors and not of the University of Bristol or Policy Press. The University of Bristol and Policy Press disclaim responsibility for any injury to persons or property resulting from any material published in this publication.

Policy Press works to counter discrimination on grounds of gender, race, disability, age and sexuality.

Cover design by Policy Press

Front cover image: istock

Printed and bound in Great Britain by xxxxxxxx

Policy Press uses environmentally responsible print partners 